\title{
Memórias do Cárcere, de Graciliano Ramos
}

\section{J. Guinsburg}

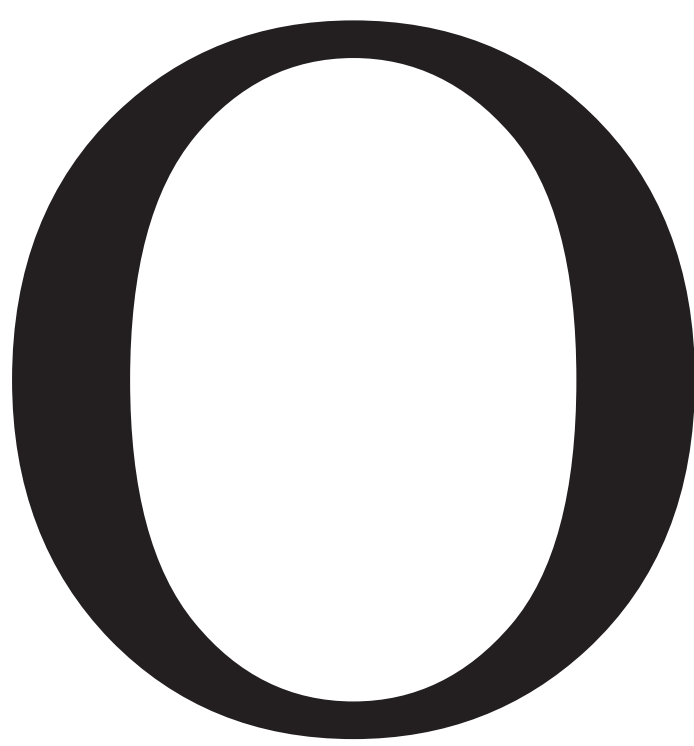

aparecimento póstumo desta obra marcou época na vida literária do país. O grande romancista trabalhara longamente em sua feitura e, dadas as qualidades artísticas, humanas e sociais de sua linha criadora, era certo que produziria um documento único na literatura brasileira. De fato, com as $\mathrm{Me}$ mórias do Cárcere (José Olympio, 1956), Graciliano Ramos legou-nos um livro clássico, o maior que já se escreveu no Brasil, sobre o tema.

Os livros de memórias e autobiográficos sofrem, em geral, de grave unilateralidade. O narrador, escrevendo na primeira pessoa do singular, poucas vezes enxerga além da primeira pessoa do singular, deformando assim não só incidentes e personagens, como a sua própria personalidade. $\mathrm{O}$ "irritante pronomezinho", mesmo contra a vontade do memorialista, destrói as proporções e engrandece de maneira descabida a figura do herói-escritor. Convertido de um ou de outro modo em elemento central, arma todo um sistema no qual os eventos

J. Guinsburg é professor de Teoria do Teatro da ECA-USP e autor de, entre outros, Boca de Cena: Marcações de um Espectador (Edusp). 
e os tipos, mesmo os de máxima importância, funcionam como satélites em torno deste sol, e visam apenas a ressaltar a relevância de seu papel.

Isso talvez fosse até uma qualidade se a autoanálise e a perspectiva artística conduzissem a obra à esfera puramente literária. Nesse caso, a visão subjetiva e a sensibilidade criadora constituiriam os próprios fatores de transfiguração da bidimensionalidade plana e egocêntrica, onde a única vivência real é a do herói autoconsagrado. O solipsismo inerente transformar-se-ia, então, no mínimo em valor estético e no máximo em experiência geral humana. É o que sucede com boa parte da ficção moderna. Podemos discordar de sua extremada interiorização, desnudar as condições sociológicas que geram essa tendência e, inclusive, condenar suas distorções. Entretanto, devemos confessar que o monólogo interior e a evocação servem de excelentes pretextos para uma visualização do mundo e do ser humano segundo a representação de um $e u$ infinito, a consciência despersonalizada do próprio autor, cuja entranhada subjetividade seria a causa e o penhor de sua total objetividade. Em sua concretização literária, tais elementos redundam no quadro e na exegese de uma sociedade, de uma classe, de uma filosofia, de uma situação, de um indivíduo, ou mesmo de tudo isso em conjunto, mas permanecem sempre como documentos únicos, singularizados pelo talento criador e pelo seu valor estético, em prisma positivo ou negativo.

Entretanto, as memórias, autobiografias e obras congêneres pretendem quase sempre o oposto. Com raras exceções, o autor começa cantando loas à sua própria imparcialidade e absoluta falta de presunção no domínio literário e termina, direta ou indiretamente, arvorando-se em juiz discricionário dos caracteres e sucessos. Ora, é exatamente nisso que o livro de Graciliano Ramos foge à regra comum. Dentro do ego, mas pelo sóbrio controle racional, pela indissolúvel ligação afetiva com a humanidade e pela força criadora, eleva-se acima do ego. Supera a sua forma plana, através da constante ampliação de seus limites e do desenvolvimento de uma perspectiva que aos poucos transcende o quadro inicial, invadindo, abarcando e formulando a consciência de outrem, a sua própria atuação e o império das circunstâncias. O escritor o consegue através de uma severa e constante fiscaliza- ção de suas impressões, da permanente suspeita no tocante ao seu próprio mecanismo julgador, da síntese entre o vigor descritivo do romancista e o rigor do incorruptível depoente. Tais elementos fundem-se não só no "retrato em quatro volumes de Graciliano Ramos", mas fundamentalmente nas três dimensões de um cárcere que agrilhoa toda uma fase da vida brasileira.

Esta profunda sondagem não surge de chofre. Com sua habitual mestria e com a angulosidade de um estilo, onde o vocábulo não ultrapassa aparentemente o seu significado imediato, o escritor efetua uma descida gradual no abismo. Neste mergulho, tanto mais doloroso quanto isento de grandiloquência e dos gritos histéricos das quedas heroicas, cada patamar parece uma saída para luz, mas logo se verifica que é apenas um degrau nas trevas...

$$
* * *
$$

$\mathrm{O}$ autor começa internando-se em si mesmo, nas penumbras de um cotidiano sem perspectivas, de uma vida cinzenta de funcionário, entediado com o ramerrão e atormentado por pequenos problemas domésticos. A sua abrupta prisão é quase um alívio, um horizonte que se distancia em linha de fuga... O seu ponto terminal é uma incógnita. Mas não importa. No momento representa uma viagem, "uma dádiva imprevista", uma escapatória do gabinete de burocrata.

Esse início deveria conduzir a obra a um eterno lusco-fusco subjetivo, decompondo os seres e as conjunturas em meras sensações, destruindo-lhes toda a substância, a fim de melhor utilizá-los como escadas da evasão. Mas desde logo surpreendemo-nos: os dados sensoriais não se fragmentam na análise interior, não se desfazem naquela poeira crepuscular filtrando-se através do vitral do eu. Ao contrário, à medida que avançamos na leitura, as impressões descritas aglutinam-se, adquirem formas precisas e linhas nítidas, moldam-se em personagens definidas e caracterizadas, estruturam-se em situações e posições insofismáveis. Sentimos uma luz vigorosa de Nordeste, eliminando todo cromatismo impressionista, incidindo diretamente na realidade, desnudando os seus aspectos mais contundentes, enfrentando-os ativamente, jul- 
gando-os sem temor, penetrando no seu imo, a fim de desvendar o seu conteúdo.

Assim, a singular viagem estende-se a territórios humanos cada vez mais amplos. À medida que o prisioneiro se abisma no seu cárcere material e espiritual, as suas memórias, a princípio um pequeno mar interior refluindo sobre si próprio, agitam-se, espraiam-se, adquirem a largura e a turbulência dos oceanos. Em suas ondas flutua uma crescente variedade de tipos e fatos, numa sucessão aparentemente caleidoscópica, desconexa e contraditória. Mas, aos poucos, através de repetidas sínteses de linhas dissimuladas, esboça-se em nossa mente uma gigantesca figura humana, de punhos acorrentados, com a amargura e a revolta impressas nos olhos. É a condição humana espezinhada em sua dignidade e em seus mais sagrados direitos.

Essa magistral forma de superação do subjetivo através de seu alargamento, da resolução de seus valores numa etapa imediatamente superior, ou melhor, inferior, pois o processo é de queda e descenso na sombria fossa da tirania e do fascismo, é, sem dúvida, uma das mais originais da literatura brasileira. Poucos escritores, partindo de análises tão impregnadas de valores pessoais, tão marcadas por uma individualidade ímpar e incapaz de se desprender de si própria, conseguiram sínteses tão autênticas, de uma realidade social e, principalmente, de todo um aspecto da vida coletiva em determinada fase. Graciliano Ramos foi, incontestavelmente, um mestre da observação e, ainda mais, de sua recriação num quadro que, por sua amplitude, por sua rigorosa composição e seleção crítica dos elementos, transcende o mundo interior do narrador, a fim de se converter em tela panorâmica e objetiva do mundo exterior e dos fenômenos.

Daí por que, no curso dos quatro volumes das Memórias do Cárcere, nos deparamos a cada passo com um extraordinário jogo de contradições que se transmutam progressivamente num todo orgânico. Esse singular desenvolvimento abrange os diferentes aspectos da obra (individuais, humanos, sociais e políticos), e começa pela própria forma literária, onde se alternam os momentos de ficção e depoimento numa unidade estilística que espanta. Os recursos da primeira completam as informações da segunda, esculpindo persona- gens, arrancando às superfícies planas o relevo e a profundidade dos ambientes.

No primeiro e terceiro volumes, por exemplo, as descrições do porão do navio e da ilha correcional acham-se, sem dúvida, carregadas de elementos de ficção. Entretanto, que notável veracidade! Os meios artísticos empregados, não só não falseiam tais atmosferas, como nos comunicam diretamente uma viva impressão de suas cores mais autênticas, de suas notas mais vibrantes, de suas personalidades mais incisivas. Contra esse fundo, os personagens (e nesse caso trata-se de seres reais, cuja apresentação não permite maior liberdade artística em relação a seus traços físicos e psíquicos) não mais parecem símbolos indecifráveis, anotações evocativas do autor, mas surgem de corpo inteiro, exibindo as almas na crua nudez de uma palavra, de um gesto, de um olhar.

Por outro lado, no segundo e quarto volumes predomina o depoimento. As páginas desses tomos desdobram-se num longo cortejo de incidentes e personagens. Contudo, o seu valor não é apenas episódico e anedótico. Integram organicamente um conjunto, ordenado não só pelo espaço do cárcere e pelo tempo de sua ocorrência, mas também por certas linhas de força e motivação, salientadas nos processos de recriação literária. Esta, como um lápis que sombreia certos traços e acentua determinados planos, ressalta a orientação fundamental dos acontecimentos, as feições marcantes dos indivíduos e o sentido de seus atos. Mas, uma vez situado nessa esfera, o depoimento perde o seu caráter de mera exposição de fatos e impressões, transformando-se em compreensão e crítica, ou seja, numa etapa superior do conhecimento da realidade.

Entretanto, não se verificam imposições artificiais e arbitrárias do autor. Embora a sua personalidade centralize e, portanto, influa na organização a posteriori dos elementos, estes obedecem a um único imperativo: o de um relato fiel dos anos de prisão. Tal fidelidade pressupõe, sem dúvida, a apresentação objetiva dos fatos, a tentativa de abarcá-los em seus múltiplos aspectos e na devida época, bem como a máxima imparcialidade possível. O julgamento surge das condições e não do condicionamento da realidade.

Ora, a completa objetividade da mente individual é irrealizável, pois tudo quanto passa por 
seu filtro se impregna de seus valores. Assim, para respeitar essa fidelidade, a fim de não viciá-la em sua origem, só resta um recurso: considerar devidamente os fatores subjetivos, detalhar as reações pessoais e sublinhar as tendências do temperamento do autor. Essa maneira de proceder assegura não só a sinceridade do relato, mas também os limites das eventuais distorções inconscientes na apresentação dos fatos, o que constitui, num trabalho individual, o máximo de exatidão possível e o máximo esforço no sentido de evitar a unilateralidade.

E, de fato, se observamos com atenção as $\mathrm{Me}$ mórias do Cárcere, verificamos que uma das principais preocupações de Graciliano Ramos é a de libertar o seu depoimento de todo e qualquer personalismo ou crítica viciosa e preconcebida. Entretanto, consciente da poderosa ação catalisadora de sua personalidade, de sua incapacidade de fugir a uma visão peculiar do mundo e dos homens, das determinações de uma sensibilidade e emotividade avassaladoras, não se desperdiçou em inúteis tentativas de se desfazer de si mesmo. Preferiu o caminho inverso, o da franca exposição de sua própria individualidade, sem dúvida o único que o conduziria ao fim desejado. A demarcação de suas fronteiras permitiu situá-la dentro dos acontecimentos, circunscrever as deformações subjetivas dos conceitos emitidos e construir uma sólida base para alcançar a procurada objetividade.
E Graciliano Ramos a alcança. O documento que nos deixou não é um mero retrato das vicissitudes de um preso político e das impressões sobre os seus companheiros de cadeia, mas a história de uma época, vista em seu subsolo humano, social e político. Ali, a prepotência e a miséria de uma sociedade, a fraqueza, a sordidez e a degradação do homem, os seus conflitos e os seus ódios, delineiam-se em linhas pungentes. Recuamos enojados ante o atroz espetáculo das torturas físicas e mentais, das delações e suspeitas, dos instintos à solta e das taras no pasto. É um sombrio e sufocante mundo de opressões e aviltamentos.

Mas pasmem-se! O crítico impiedoso, o grande pessimista, crê no homem. Chocado com as suas próprias revelações, procura e desvenda com mãos trêmulas o ser humano na sua capacidade de sacrifício e na sua solidariedade desinteressada, na sua resistência ante as forças que o degradam e na sua luta por um mundo melhor. É quase com orgulho que Graciliano nos mostra o Capitão Lobo, o negro que lhe oferece água, várias figuras de prisioneiros, as esposas dos encarcerados e o próprio Paulo Turco. São momentos de mal dissimulada confiança no homem e na sua redenção. São inesquecíveis flagrantes de Memórias que se gravaram na memória de seus leitores e da literatura brasileira.

1956 